\title{
The Resource Potential of the Participating Countries of the Eurasian Economic Union
}

\author{
Prof. Dr. Saulesh Kalenova (Turan University, Kazakhstan) \\ Prof. Dr. Rahman Alshanov (Turan University, Kazakhstan) \\ Prof. Dr. Ali Abishev (Kazakh Economics University, Kazakhstan) \\ Prof. Dr. Valentina Gerasimenko (Moscow State Lomonosov University, Russia)
}

\begin{abstract}
Against the background of international openness and globalization of the world economy, it is very difficult to achieve higher competitiveness in the state without the support of friendly neighbors. In this age of competition of constructive ideas, high technologies, knowledge-intensive the problem of innovative development of the Republic of Kazakhstan in the context of the Eurasian Economic Union became central dominant of understanding the goals and methods of reforming the modern state economy.

The main ambitious goal is a breakthrough of Kazakhstan in the 30 most competitive countries of the world. This goal promotes the development of a coherent policy of modern developments management and the formation of a national innovation system with effective mechanisms of interaction between government, business and science in the context of the EEU. Kazakhstan tries to integrate experience of developed countries into this process. These countries began their journey to progress from the unification into regional economic alliances.

The article analyzes the integration processes and actions of economic activity of participating countries of the Eurasian Economic Union in the new environment. It also examines contemporary processes of globalization and the necessity of creating an economic union, particular features of the regional economic communities. The article includes materials of the Eurasian Economic Union historical background. There was conducted analysis of integration processes development in the economic environment on the example of post-Soviet states joined in the Eurasian Economic Union.
\end{abstract}

\section{Introduction}

There are certain challenges to achieve higher competitiveness for any government against the background of the international openness and globalization in world economy if there is no friendly support from the neighborcountries. Innovative development of Republic of Kazakhstan in the context of the Eurasian Economic Union (EEU) has become central dominant in understanding of the goals and methods to reform modern state economy in age of competition in constructive ideas, high technologies and science intensity.

The main ambitious goal is to breakthrough Kazakhstan to 30 most competitive countries in the world, which has set by the state leader. This goal supports in elaboration the coherent policy in managing the modern developments and formatting the national innovative system with effective mechanisms for interaction between government, business and science in context of the EEU.

Kazakhstan is trying to integrate the experience of many developed countries to this process. These countries began their journey to the progress from the joining them to the regional economic unions. Practically, separate state cannot exist apart from other countries, without joining to variety of economic relations, which nowadays are not limited by foreign trade and barter. These include an allocation of financial capital between countries, labor migration and of course scientific and technical exchange. While, none could forget own national interests.

Taking in account the time of being part of the Soviet Union from 1922 to 1991, when Superpower was located on the sixth part of the Earth, there were long-term history of political and economic community of the post-Soviet states. Union was considered as a common system in political, legislative and executive aspects. The short period of disunity by historical measures (since 1991) has shown the possibility of independent political development of world is largest state - the USSR, which has collapsed at one time. However, economic disunity could not enrich the post-Soviet independent countries and we have repeatedly returned to the different kinds of integration, such as Eurasian Economic Community (EurAsEC), Common Economic Space (CES), the Customs Union (CU), a free trade area (FTA).

Russia, Belarus and Kazakhstan are countries, which have been absolute partners in all these integration models despite arisen problems, improvement or deterioration of the political, economic, migration and other spheres. We understand and realize that even the most highly developed country cannot provide all their needs without friendly unions. At present stage of development of world economy, set of national economies, as well as their economic and political relations, acquire totally different quality. Considering that a process of globalization covers all countries of the planet in varying degrees, we are talking about important phenomena: 
internationalization of economy, development of a unified system of the world relations, change and easing the state functions, revitalization of transnational corporations.

The second half of the XX century was characterized by growing interdependence of national economies, contributing to formation of an integrated world economic system, which determined internationalization of production. During this period, many countries began to shift to a new type of international socialization of production called «integrational». The objective necessity of such a move was due to the whole course of world economic development, caused by the current problems and cannot be resolved by states neither without any help nor on the basis of old system of international division of labor. Dynamic changes occurring in the global economy refer to developed countries and developing countries, and also emerging new emerging markets.

Usually globalization of economy is understood as a rapid increase of flow of goods, investment, credit, information, human resources and exchanges of ideas, as well as expanding geography of their distribution. Speed, intensity and penetration depth of the flow increase to a point where national economies become interdependent. Elements of national economies (national producers, consumers, financial and other institutions) are directly integrated into the overall world economy. As a result, domestic producers are increasingly linked to foreign consumers. If earlier there was a quantitative increase in the interaction of individual national economies in the form of an increased flow of goods, capital and investments, today there is a qualitative change in their interaction.

\section{Advantages and Disadvantages of Globalization}

Let us consider the distinct features of the onset of a new stage in development of global economy, to which we refer:

1) openness as main principle of any country and the world community relations, expansion of world trade at the active liberalization of foreign economic activity;

2) formation of regional entities aimed at integration and interaction of separate states' economies, use of a sufficiently reliable and effective regulatory mechanisms of economic cooperation between countries;

3) growth and widespread usage of transnational companies, which increasingly play a decisive role in international investment and trade policies;

4) intensive development of high and advanced technology, computer science, etc., which leads to rising of productivity, closer connection of individual countries and regions markets;

5) establishing systems of international organizations ensuring stable and balanced economic development of world and national economies;

6) formation of international trading system based on internationally accepted rules and conditions of crosscountry migration of labor, capital and technology;

7) general functioning of financial sector, not directly related to foreign trade and international movement of factors of international production.

Based on active promotion of these processes from the $1980 \mathrm{~s}$, current period of globalization of the world economy has been originated. It subsequently resulted in the formation of a single coherent space thanks to further development of global market of transnational capital, new technologies, providing a qualitatively new level of economic ties.

The impact of globalization on world economy, as a rule, is tracked through traditional macroeconomic indicators. However, we may see more meaningful analysis of the impact through the most important characteristic manifestations of modern times, which include the following:

1. Informational and technological revolutions

2. Easing of movement of goods, services and capital

3. Development of the tertiary sector of the world economy

4. Qualitative breakthrough in the development of international capital market

5. Strengthening of the power and value of industrial and banking transnational corporations

The general result of all the mentioned factors is an increase of interdependence of national economies as one of determining features of the global community.

Globalization should be understood as a new stage of internationalization of economic life and growing economic cohesion of countries around the world as a result of increasing volume and diversity cross-border movement of goods, services, and international capital flows, as well as through more rapid and widespread diffusion of technology.

Costs and benefits of globalization are distributed among its participants extremely uneven. Increase of productivity, reduce of costs, increase of income and wealth at one pole is achieved at the cost of increasing 
uncertainty, risk, inequality, and poverty on the other. As these costs and benefits, unity and contradiction of interests simultaneously manifested not only in individual countries but also far beyond them, problems cannot be solved only through international cooperation.

With regard to benefits of globalization:

- Firstly, it has caused aggravation of international competition. Healthy competition and market expansion lead to greater specialization and international division of labor, stimulating, in its turn, increase of production not only at national but also at global level;

- Secondly, globalization leads to economies of production scale, which could potentially lead to reduced costs and lower prices, therefore, to sustainable economic growth. It can provide an increase of productivity as a result of streamlined work processes at the global level and distribution of advanced technologies, as well as competitive pressures for continuous innovation on a global scale;

- Thirdly, positive traits of globalization are also associated with gains from mutually beneficial trade satisfying all parties, who may be individuals, firms and other organizations, states, trade unions and even continents.

In general, globalization can improve position all partners receiving opportunity to raise wages and living standards by increasing production. Its end result should be general welfare of the planet.

At the same time, despite advantages of globalization, this process is in world economy, new hotbeds of conflict and controversy.

Firstly, there is a rapidly increasing gap between weak and strong countries, which is explained by an abrupt increase of unequal exchange. World Economic competition is reduced in a similar situation to the struggle between industrial states' rights and a possibility of supplying their products in industrialized countries.

Secondly, it is on the basis of deformation of globalization of financial and market mechanisms. This is manifested through generalized anti-liberal rebirth tools of competition: it degenerates, turning into its opposite. And it does not spur lagging, does not encourage them to build competitive advantage, and destroys many of those who in other circumstances would have had a chance to survive. Moreover, this applies not only to business entities, but also of entire countries.

Thirdly, serious threats to sustainable development of economy comes from excessive expansion international capital, especially speculative, sad consequences of one can observe in people's life. Now most of the capital under influence of new global benefits commensurate with ordinary profit, reoriented to speculative enrichment. Powerful waves that are born from Him Nakata destabilize economies of not only weak, but also strong states.

Fourthly, changing the very nature of the world's GNI (gross national income). It quickly increasing the share of high-tech products. Production information and related products becomes most important indicator of economic growth. Human, intellectual capital is increasingly acquiring the features of a direct productive force. Its quality is transformed into the main indicator of the level of development of countries and regions.

Fifthly, globalization is associated with potential regional or general instability, due interdependence of national economies in the world. Local economic fluctuations or crises in one country can have wide-ranging, even planetary consequences. This danger is not only theoretical, but it is quite realistic, which is confirmed by recent global financial crisis. Such disasters show great vulnerability of interconnected economies, and current prolonged sluggish global crisis confirms this.

Sixthly, it is suggested that the control of the economies of individual countries may go from their governments in other hands, including the strongest powers, transnational or global corporations and international organizations. Because of this, some look at globalization to as an attempt to undermine state sovereignty. Such sentiments can easily go to extreme nationalism with calls for protectionism, lead to the growth of extremist political movements that potentially lead to serious conflicts. Strengthening the same state and its institutions is a prerequisite not only of survival, but also the nation's development in the context of globalization. It does not die, moreover, can and should take strategic functions of participation in these processes.

\section{The Influences of Global Economy on Kazakhstan}

In general, recognizing globalization as an objective process should be perceived as a challenge to nationstates, as well as new opportunities for them. For the Republic of Kazakhstan following negative consequences on globalization can be applied:

- Consolidation of the Kazakhstan raw specialization in the global economy;

- Reducing a role of government in the context of globalization and increasing a role of international organizations;

- $\quad$ Threats to Kazakh national business, which cannot to compete with multinational corporations (TNCs); 
- Increase of the impact of external forces on political situation in the country.

- At the same time, globalization brings to Kazakhstan the following benefits:

- Attracting investments for development of economy;

- Ensuring a balance of foreign policy, using complex geopolitical environment of Kazakhstan;

- Development of international economic cooperation;

- $\quad$ Strengthening cooperation in the field of security;

- Bringing new technologies to the Republic of Kazakhstan to raise quality level of our economy;

- Assistance from international community to address social problems such as poverty, unemployment, and ecology.

To use the opportunities of globalization one needs to develop competitiveness economy, to develop regional integration, improve the system of governance, determine the country's development strategy in the context of globalization. However, it is obvious that the above factors that have a direct impact on it will develop in the future, therefore, the process of globalization, apparently will only accelerate.

Thus, the modern economy is becoming the norm, when medium and small company previously focused mainly on the domestic market; feel free to go to the markets of other countries steadily increasing their share of exports.

At the current stage of development of globalization, there is increasing interdependence of national states and regions, forming the world community, their gradual integration into a single system common to all rules and regulations of economic, political and cultural behavior. At the same time, globalization is a dual process developing in interstate and transnational forms. Hence the multiplicity of its carriers: country, their coalition, international organizations, non-governmental entities, transnational corporations and even some individuals (Bill Gates, George Soros and et al.). Sphere of special interest are the national economies developing their activities on background of globalization. Positive developments in the international economic relationships by globalization and integration of national economies were main prerequisites for emergence of the post-Soviet Eurasian cooperation in its various versions.

A model of strong economic mutual cooperation are:

EU (European Union)

NAFTA (North American Free Trade Agreement)

APEC (Asia-Pacific Economic Cooperation)

Mercosur (Economic Community of South American countries)

EFTA (European Free Trade Association)

SADC (Southern African Development Committee)

UEMOA (West African Economic and Monetary Union)

SAARC (South Asian Association for Regional Cooperation) and others.

All listed integrations represent different models of cooperation and exist in different economic conditions and as such no one of them may be the best example of integration for others, nevertheless it is difficult to imagine development without integration. All above-mentioned alliances between countries arise certain tensions, misunderstandings of economic nature, however without integration of the world community modern national economies can hardly survive at all.

So, summing up the foregoing, it can be noted that, firstly, the development of international trade has provided a deeper division of labor between countries and contributed to further integration of national economies into the world. Therefore, firms from different countries have become to seek more favorable conditions for their business in foreign markets, through development of which they would be able to increase the volume of production and deepen specialization.

From 1 January 2015 the economic relations between the participating countries of EAEC, namely Russia, Kazakhstan, Belarus, Armenia reached a qualitatively new level. In May 2015 Kyrgyzstan will join this union. Therefore, we consider it appropriate to conduct further analysis of the economic parameters of the five states with the Kyrgyz Republic.

Already today it is the first in the world economic community in surface area is more than 20 million sq. $\mathrm{m}$. $\mathrm{km}$, giving the GDP according to the IMF (5th place in the world community) on the amount of 4.0771 trillion US dollars.

As we noted above, economic integration and cooperation shall be construed as mutual adaptation of individual sovereign states, when we are talking about close mutual cooperation in the field of efficient division of labor, free movement of goods, services, capital and labor. It is not a secret that products are released for domestic market and as such always has a sufficiently high cost due to high production costs and low product 
sales opportunities within its own market, respectively the price higher than the average, and the product or service becomes noncompetitive. Also it is absolutely clear that no nation can develop and compete in all areas of the economy. Today it also became clear that Kazakhstan plays in such areas as production and sale of agricultural products, trade in petroleum products (gasoline and diesel) automobile, but its business is also not competitive. Therefore it is important to examine what the advantages, potential of our country are, where we can get a win in the development of our state.

The model of mutually advantageous integration and cooperation between the states is defined by unambiguously historical community of communications, a complex of geo-economic and geopolitical factors, a similar vector of economic development at the heart of which there is a resource potential. At the same time in the course of formation of integration communications there are complex methodological problems on which success of international integration considerably defining destinies not only of people of certain countries, but also the whole continents in many respects depends. The combination of complexity and high responsibility of the made strategic decisions does this area of research especially significant.

Russia and Kazakhstan play a huge backbone role in development of multilateral integration at the Eurasian space. Considering that domestic markets of majority of countries of the former Soviet Union in modern conditions are insufficient for development of even rather small part of productions, especially knowledgeintensive, they have to seek for association as it does a majority of industrialized countries.

Besides, for development of interstate cooperation of the former Soviet republics there is certain bases in the form of complementary productions and general technologies, structural development increasing competitiveness of national farms, and also traditional cultural and public relations.

Many representatives of member countries of EEU peculiar interpret our union. Opinions that it is not favorable to Russia to approach the weak states move forward. In the Kazakhstan press there were also many discussions on necessity of entering the union and development of our economy without participation of neighboring states. The example of 2014, when the Russian Federation was attacked by various sanctions from foreign states confronting in the political plan, which naturally painfully struck on economy, according to and on the social growth of our neighbor.

Kazakhstan in principle is economically the least vulnerable party as possesses considerable minerals. So, from 105 elements of the table of Mendeleyev in a subsoil of our republic 99 elements are revealed (stocks on 70 elements are reconnoitered and more than 60 elements are already involved in production). 493 fields containing 1225 types of mineral raw materials are reconnoitered. On the volume of reserves of minerals our Republic wins first place among the CIS countries on chrome ores and lead, the second - on reserves of oil, silver, copper, manganese, zinc, nickel and phosphoric raw materials, the third place - on gas, coal, gold and tin.

2014 for the Republic of Kazakhstan in the economic plan, without watching in general at world problems. So, GDP growth in 2014 to previous year made 104,3\%, while GDP growth in the Russian Federation made 100,6\%, in the Republic of Belarus - 101,6\%, in Kyrgyzstan - 103,6\%.

At the same time in absolute expression of GDP of the Russian Federation is much higher, than in the Republic of Kazakhstan and the Republic of Belarus. So, GDP of Russia in 2014 made 1869,3 bln. US dollars (including, at the expense of the industry of 1143,2 bln. US dollars, at the expense of agriculture of 109,8 bln. US dollars), in the Republic of Belarus - 75,9 bln. dollars of the USA (including, at the expense of the industry of 64,1 bln. dollars of the USA, at the expense of agriculture of 10,8 bln. dollars of the USA), in the Republic of Kazakhstan $-212,2$ bln. dollars of the USA (including at the expense of the industry of 99,9 bln. dollars of the USA, at the expense of agriculture of 14,0 bln. dollars of the USA). However one should not forget that population Kazakhstan (17,3 million people) is much smaller than that of Russia (146,3 million people).

In the directions of investments into fixed capital our republic advances this indicator across Russia (investments into fixed capital as a percentage to previous year made in Kazakhstan 103,9\%, in the Russian Federation $-97,5 \%$, to Belarus - 91,5\%).

GDP per capita in 2013 in dollar expression made 13612 US dollars that is not much lower than in the Russian Federation - 14618,8 US dollars in Kazakhstan, but is much higher, than in Belarus - 7498,7 US dollars (fig.1). 


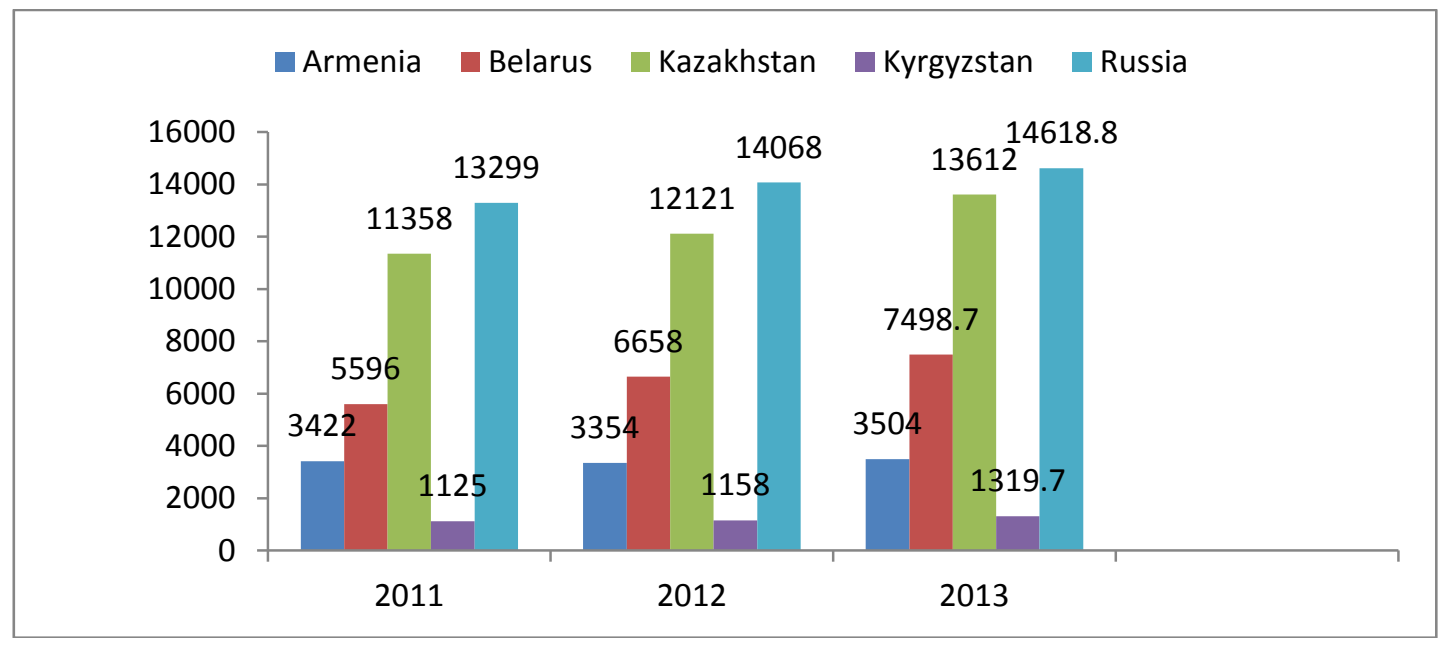

Figure 1. The GDP of the EEU per capita (US dollars)

It is necessary to be realist and to tell that, despite positive tendencies of economic development of the Republic of Kazakhstan, we much more lag behind on a standard of living of the population the Russian Federation (fig.2).

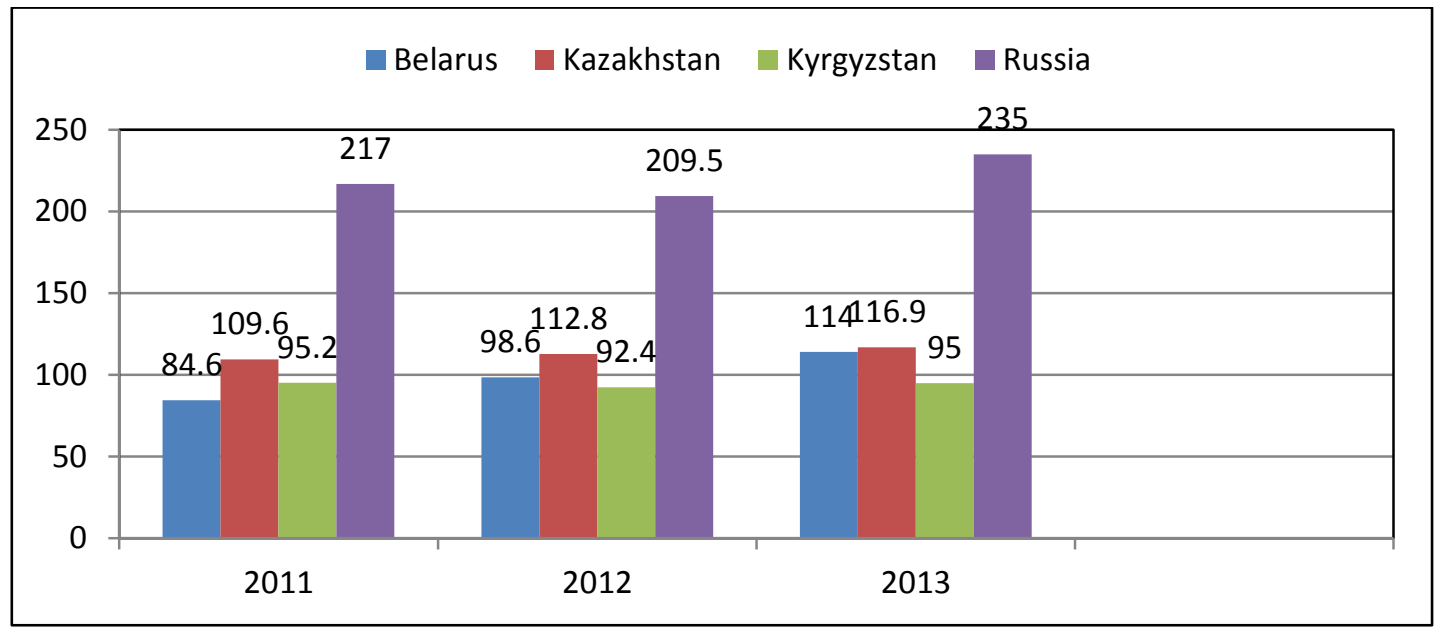

Figure 2. The minimum subsistence level of the EEU (US dollars)

So, in Russia the size of a living wage according to 2013 makes 235 US dollars, the average size of pension 315,5 US dollars, in Kazakhstan these figures much lower and make 116,9 US dollars and 206,3 US dollars respectively. It is remarkable that unemployment rate in Republic of Belarus is much lower, than in Kazakhstan and Russia (0,5\% against 5,2\% and 5,5\% respectively) (fig. 3 ).

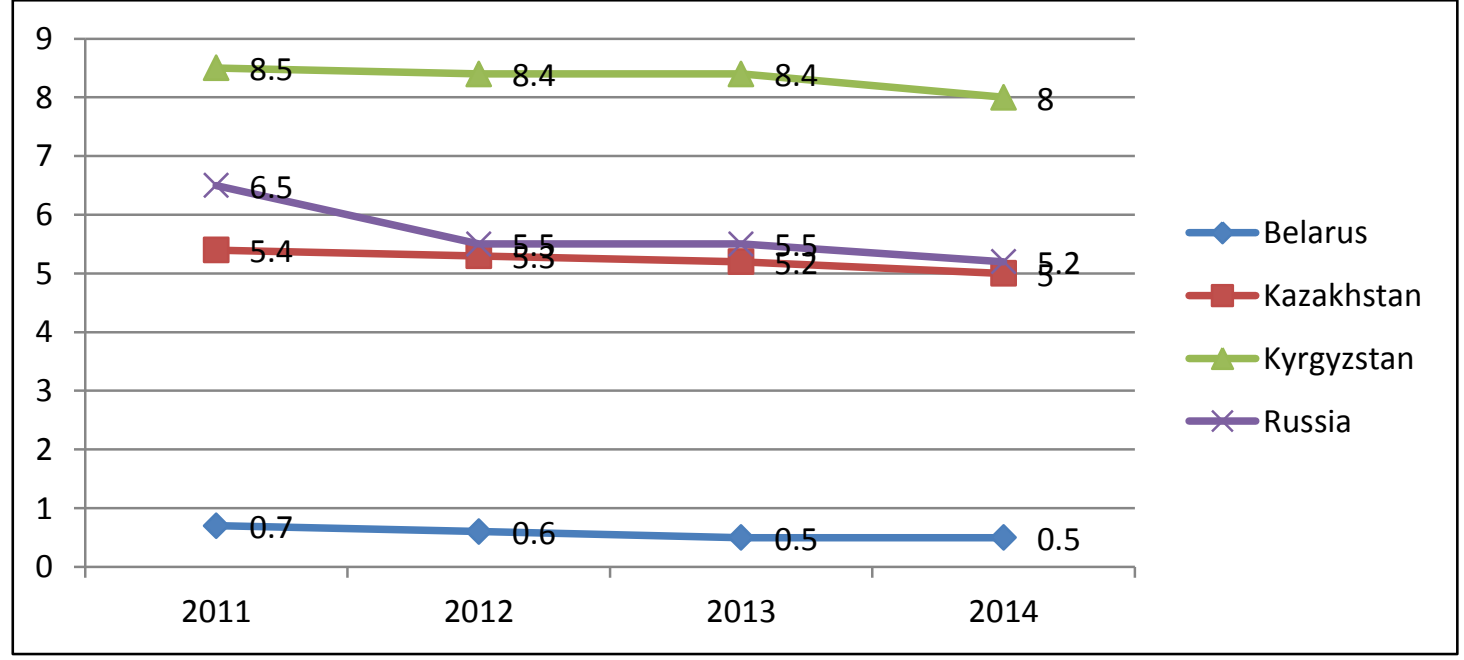

Figure 3. The unemployment rate of the EEU (in percent) 
The analysis of a foreign trade turnover shows that Russia much more advances other countries of EEU (fig.4) on these indicators.

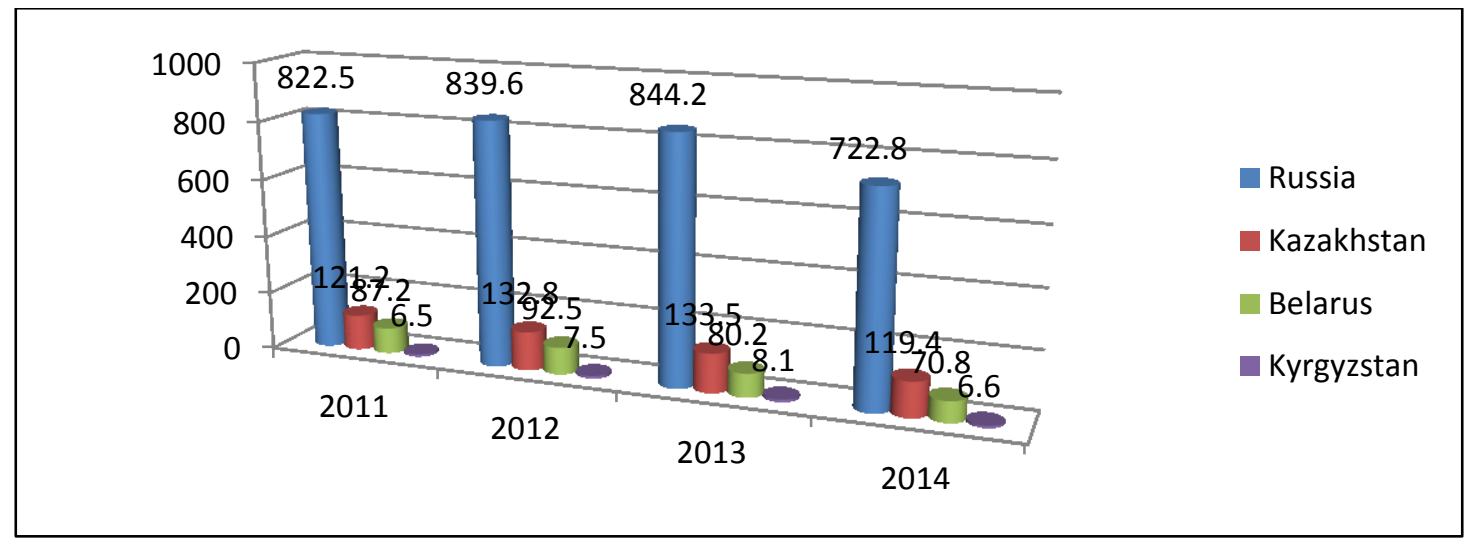

Figure 4. The foreign trade turnover of the EEU (billion US dollars)

It is a gap it is considerable as on export (fig.5)

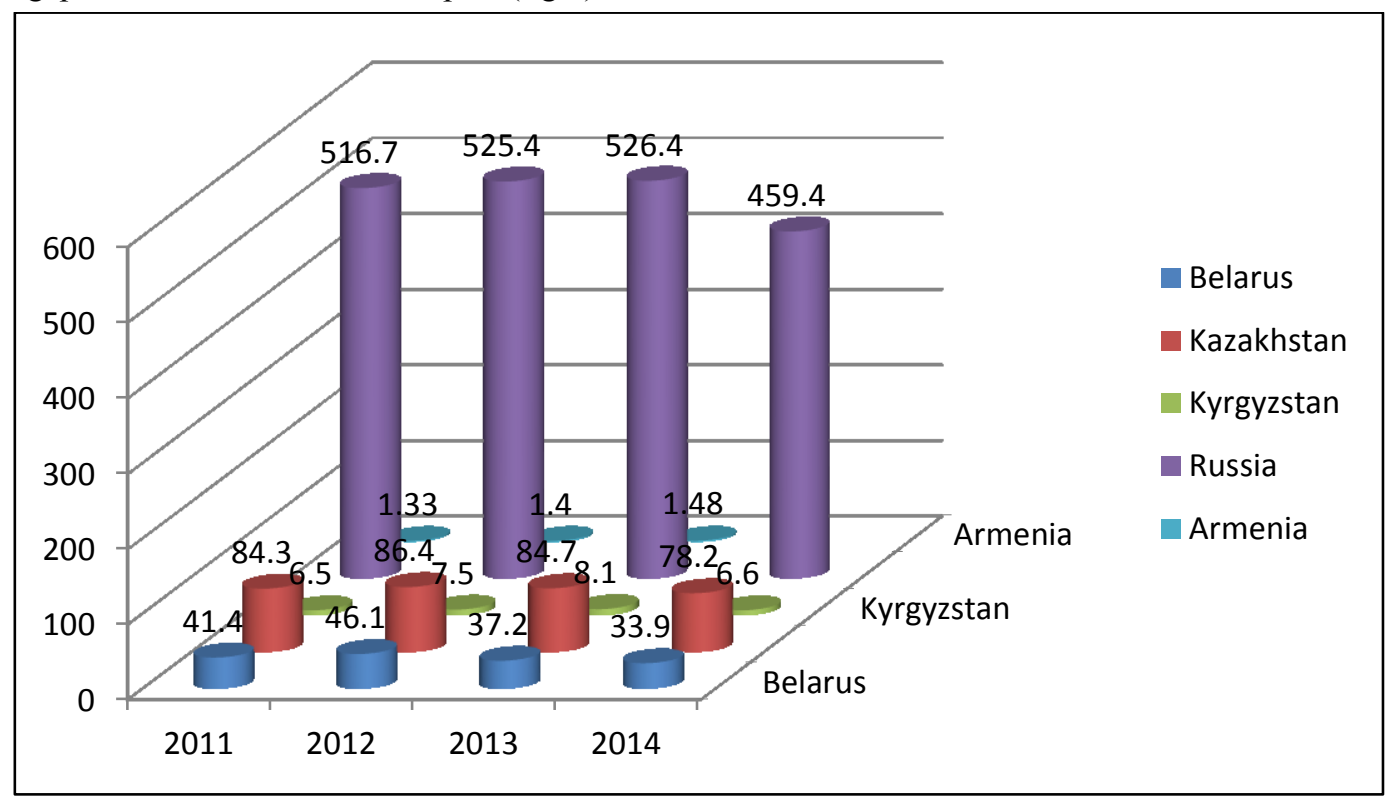

Figure 5. The volume of exports of the EEU (billion US dollars)

and on import (fig.6)

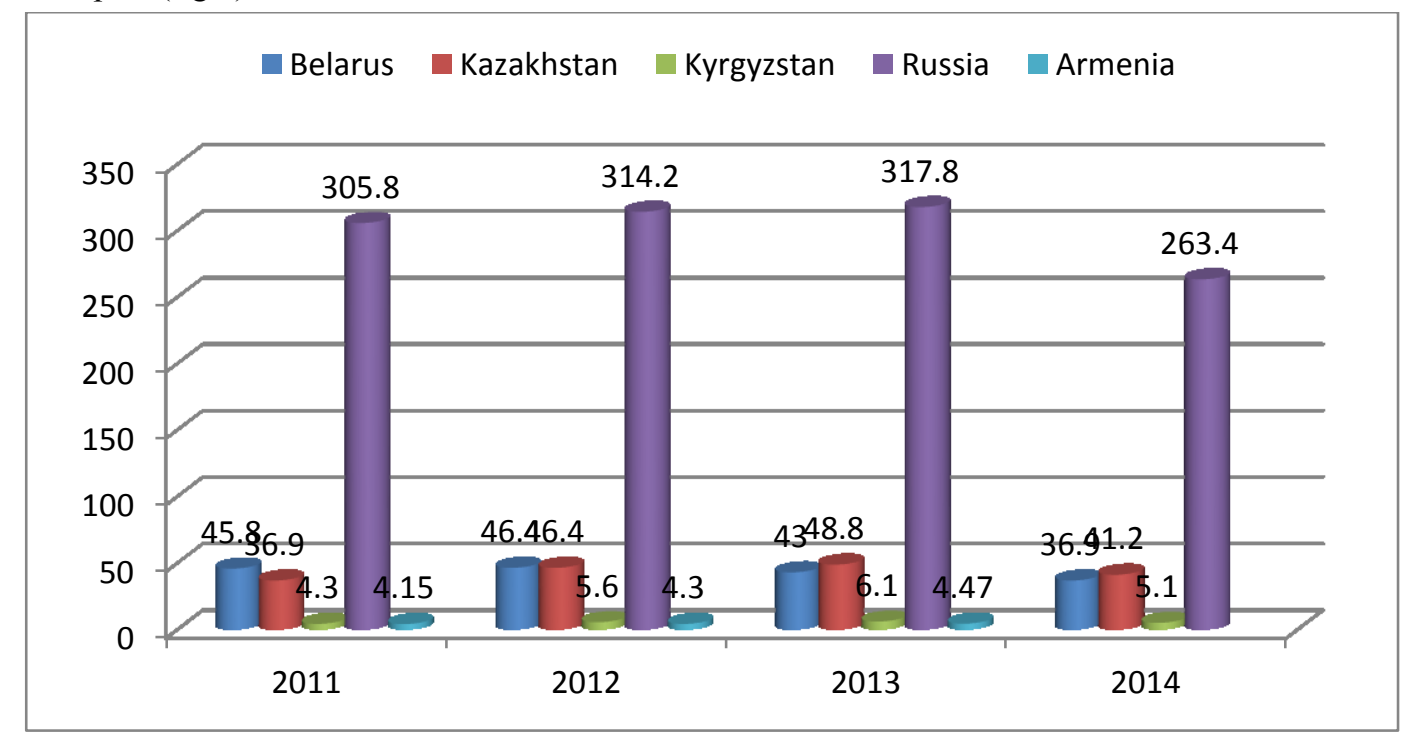

Figure 6. The volume of goods imports of the EEU (billion US dollars) 
We subjected to the detailed analysis data in one year, but in dynamics as show, the data presented in charts, special deviations in recent years since 2011 occur.

Unfortunately, as we noted above, the negative moments in Russian Federation economy, which might affect the commonwealth economic countries of EEU have occurred in 2014.

Therefore, in our opinion, identification of integration potential, current trends of development and possible consequences of formation of a common economic space, development of perspective directions of innovative development and modernization of economy of the countries are crucial. New forms of integration demand theoretical judgment and correction of developed paradigm of the analysis of the international economic integration. Besides, there are still certain fundamentals as a complementary industries and common technologies, structural development, which increase competitiveness of national economies as well as traditional cultural and public relations for former Soviet republics' intergovernmental cooperation development. This is important especially for Kazakhstan, which unfortunately has a small domestic consumer market.

Kazakhstan generally is associated with the fast-growing market. Despite significant influence of international financial crisis, which caused also the economic activity recession in Kazakhstan, our country quite quickly succeeded in restoring the economic growth rate.

In order to reach successful competition and corresponding increasing of national wealth fare there is a strong need for Republic of Kazakhstan in standing more actively against existing bureaucracy, corruption, and government administrative pressure on business processes and propagandizing more actively investment attraction of our state. There is also a need to take in account downward tendency in level of world prices on hydrocarbons and reduce budget dependence on oil income at the same time plan expansion of the transport corridors due to increasing of the capacity of "KTK" and "Kazakhstan-China" oil pipelines.

RK government should: 1) direct more efforts in modernization of agro-industrial complex, increasing of business activity in underdeveloped regions, provide an integrated approach in modernization of economy, i.e. finance programs, which give the greatest multiplicative effect on growth of economy and employment of the population; 2) provide a targeted public support to fight the price collusion and unfair competition through the containment of prices for socially valuable food products; 3) consider the world financial markets situation; 4) continuer further macro prudential regulation in financial system; 5) work on improvement of quality of credit portfolios; 6) institute flexible tax regime within EEU, that could allow to attract additional resources for further economic growth due to the absence of restrictions on capital allocation.

Must be evidently clear that despite significant progress there is still a need in further substantial improvement of regulatory environment in Kazakhstan. There is also necessity in increasing of the level of transport infrastructure, logistics and, definitely, in activisation of the innovative activities in the current technological century.

Kazakhstan has to use competitive advantages, including considerable reserves in minerals, geographical location between markets of China, Europe, Russia and Middle East, positive macroeconomic forecast, sustainable relationships with main business partner. Kazakhstan has to continue also focus on development the state social and economic infrastructure in order to realize fully its economic potential and increase its competitiveness.

\section{References}

- Brzezinski Z., 1998. The Grand Chessboard: American Primacy and Its Geostrategic Imperatives. Basic Books, New York.

- $\quad$ Porter M., 2008. Competitive Strategy: Techniques for Analyzing Industries and Competitors. Free Press, New York.

- Samuel P. Huntington, 2011. The Clash of Civilizations and the Remaking of World Order. Simon \& Schuster.

- Stiglitz, Joseph E.; Charlton, 2005. Andrew. Fair Trade for All. How Trade Can promote Development. Oxford University Press.

- $\quad$ www.stat.gov.kz, 2015 